\title{
Louis Hennepin on the Native Americans
}

\author{
Johanna Auberger
}

\section{Introduction}

When the Europeans set out to travel to America, the mysterious new continent discovered by Christopher Columbus in the $15^{\text {th }}$ century, their reasons for doing so differed greatly. Whereas some went for the sheer aim to explore, others tried to set up trade relations, while again others tried to spread their beliefs to the unknown people they wished to encounter. One of the individuals who tried to spread believes was the Missionary Father Louis Hennepin, who was sent on a mission in 1675 by the French King Louis XIV. His goal was not only to explore new land, but also to convert the so-called "savages" to the one true faith, which according to him was Christendom. During his travels that he conducted with Rene-Robert Cavelier, Sieur de la Salle, he did not only happen to become the first eye witness to write about the Niagara Falls, but also the first European to explore the St. Anthony Falls on the Mississippi river. The contact to the Native Americans he needed in order to achieve his mission was not difficult to acquire. He was even captured and taken hostage by the Sioux at one point during his journey. However, he soon realized that the conversion itself was a much more difficult task. Due to his frequent contact with the natives, they are very present in his writings. In most of his elaborations he writes in a neutral way, but he also describes the American tribes being "The Other," which shows his negative sentiments about them. Therefore, this paper is analyzing Hennepin's writings about the Native Americans, and explores the different factors that influenced 
his writings. In order to explain these factors, this paper uses references of literature on different possible influences, such as literature on the code of conduct in Europe during the $17^{\text {th }}$ century, secondary literature on Missionary and travel writings in the $17^{\text {th }}$ century, as well as Norbert Elias book The Civilizing Process.

\section{The French Missions to North America}

During the time Hennepin was on his mission in North America, several other European Countries had sent their missionaries and explorers to the unknown continent. Characteristically, significant differences can be acknowledged between the approaches of the different countrymen. According to Benjamin F. French, the Spanish put most of their emphasis on accumulating gold and conquering North America, whereas the English established permanent residences, concentrated on agriculture and commerce, as well as sought self-governance, independent from the British crown. The French colonists on the other hand tried to gain the goodwill of the Native Americans in order to establish trade relations. Even though trade was one of the most significant reasons for the French kings to send out explorers, the propagation of Christianity can also be identified as another important factor. Therefore, they not only sent explorers, but also equipped each expedition with priests to spread the Christian doctrine (French, 1846, pp. 8-9).

The first French settlement that was a lasting foothold for northern Catholicity was established on Boon Island (Maine) in 1608. What was exceptional about the French Catholic missions was the gradual but steady conquest of new areas. Similar to the Spanish, the French kings put much emphasis on the conversion of the Native Americans to the Catholic faith. Cartier, who was a noteworthy explorer himself, was sent to the new continent "in order the better to do what is pleasing to God, our Creator and Redeemer, and what may be for the increase of his holy and sacred name, and of our holy mother, the Church" (Shea, 1855, p. 123). While the Spanish set out with a missionary corps consisting not only of clerics but also of soldiers, converted Indians, and mechanics. The French priests "planted their cross among the heathen" (Shea, 1855, p.128). By doing so, the priests converted those who were open to their thoughts about Christianity and formed Christian villages. These villages acted as forts in times of danger, but the natives remained within their tribes as free Christians. Especially after 1625 the French missionary activity took off. Missionaries of the Order of Jesuits soon arrived with the task of converting the native population, but faced hindrances by their fellow Europeans who destroyed their mission by violence. However, their steady conquest continued and new and safer settlements were established, such as one in Quebec. Six waves can be identified between 1625 and 1763 (Shea, 1855, p.123-128). 
When the French arrived in North America, they found themselves confronted with a war between different Indian nations, which did not spare the French settlers. Furthermore, they engaged in a war against the Irquois people, who were described as the most cruel and war-driven of all Indian tribes. The war that the French led against the Iroquois was characterized by great losses on both sides and lasted for many years. Only in 1668 did the rivaling parties conclude peace, which was of great importance to both the French and the Indians. With peace established, not only were the French explorer's journeys facilitated, but also the French traders could now leave their settlements to travel into the Indian territory. Catholic missionaries had always been an important part of the trading journeys, with at least one priest accompanying the traders. Even though the missionaries certainly acted in their orders interest to spread their belief to the natives, most knowledge of French and Spanish colonial history can be accredited to their writings (Stoddard, 1812, pp. 9-13).

Hennepin's first fellow Recollect priests arrived in 1615 (Shea, 1855, p.124). Despite the difficulties the missionaries faced due to the nomadic tendencies among the tribes they intended to convert, excitement among aspiring missionaries in Europe grew; Hennepin would be one of them (Shea, 1855, p.125). This excitement did not stop short of women's orders, who showed the natives their work in practice, working as hospital nuns and sharing their knowledge with the natives (Shea, 1855, p.125).

\section{Louis Hennepin}

Louis Hennepin was born on 12 May 1626 in the town of Ath, Belgium. For a long time his roots have been unclear. Louant wrote in his biography about the missionary "Oui des cinq fils Hennepin est le P. Louis?”, “Who of the five Hennepin boys is P. Louis?” (Louant, 1950, p.196). The reason for this confusion is that Louis is only Hennepin's name in the religious order of the Recollects, and not his given name. Louant concludes, that most probable the future Father Louis Hennepin had been baptized Antoine Hennepin in 1626 (Louant, 1950, p.198).

Even though Hennepin's family was not very rich, he could continue his studies until the age of 17. After finishing his studies, he joined the religious order of the Franciscan Recollects. During one of his apostolates, which led him to the French city of Calais, he found his passion in traveling while listening to the stories from the captains of the numerous ships that anchored in the harbor (Anonymous 2013). Leaving his new found passion behind, he left the French harbor town to settle in the Netherlands where a war between the French and the Dutch was taking place. During this war, which started in 1672 , he showed his devotion as a chaplain for wounded soldiers. Through the military 
work, Hennepin was stationed in Maastricht during the year of 1673 (Lemay, 1937, p.26). It was also in the course of this war in 1674 that Hennepin became friends with a person that would take the role of his savior at a later point in his life, Daniel Greysolon Dulhut (Anonymous 2013). In 1675, Louis XIV demanded five missionaries of the Franciscan Recollects to be sent to New France (Anonymous 2013 a). At the age of fifty and equipped with much experience in traveling and different religious occupations, Hennepin was chosen as one of five missionaries and set out to the new continent within the same year (Louant, 1950, p.198).

Louis Hennepin and four of his fellow missionaries arrived in Quebec on the sixteenth of June in 1675 where they met Monseigneur de Lavel and Robert Cavelier Sieur de la Salle. Whether or not the companionship between Hennepin and La Salle had been decided upon before his arrival remains unknown. Before setting out to explore the New France, Hennepin occupied himself by building a chapel and residences for future missionaries at Fort Cataracoui. Hennepin and La Salle could only start their exploration three years after the missionary's arrival, as they did not have the permission by their king until then. When La Salle returned from France with the authorization for both of them to start exploring the area between New France, Florida and New Mexico, they could finally launch their journey. The group left on the eighteenth of November in 1678 and made their way down to the Great Lakes. They arrived at the Niagara Falls half a month later, during the first December days, and continued their way to Fort Crevecoeur, where they found themselves in a rather difficult situation with many people stranded at the fort and the food becoming scarce. La Salle then decided to make his way back to Niagara but had to do so without his companion Hennepin. The latter apparently decided to further explore the unknown territory and never saw La Salle again (Anonymous 2013).

From that point on, Hennepin's stories get very disputed. It is unclear when he arrived in Paris, but it is estimated that he arrived there between 1681 and 1682 where he later published his first book (Louant, 1950, p.205). In his first book, published in 1683 he clearly mentions that he did not go down the Mississippi River due to lack of time granted to them by their nations. In his a book published in 1697 however, he claims to have done that exploration on his own, years before La Salle could set out to do so. The late La Salle could not say anything to his defense as he has been assassinated a decade before the publication. What Hennepin mentions in both versions of his story is the capture by the Sioux in April of 1680. To his rescue came an old acquaintance, Daniel Greysolon Dulhut, who negotiated the liberation of him and his two companions.

Due to Hennepin's long silence about the story he claimed to be true, he was generally perceived as a liar who tried to get fame by claiming to have made the discovery of 
the Mississippi River for which La Salle was famous. The French especially held great resentment against him, and Louis XIV even threatened to imprison him in case of his return to France (Anonymous 2013). In 1701, 75-year-old Hennepin uttered the wish to return to North America, however he never did (Louant, 1950, p.198).

\section{Publishing the book}

Louis Hennepin wrote three different books about his travels in North America. The first book was Description de la Louisiane, with the first edition published in 1683 in French, followed by Nouvelle Decouverte first published in Utrecht in 1697, and his final book Nouveau Voyage from the year 1698. Beschryving van Louisania, the Dutch version of Hennepin's first book was published in 1688 and is currently in the possession of the Jesuit Library of the University of Maastricht. From these three books, more than 50 different editions have been published in 6 different languages. The book mostly used in the analysis below, the Nouveau Voyage, had more than 15 versions published. The many publications of all three books reflect the big success, despite the accusations of plagiarism (Lemay, 1933, pp. $21-25$ ). When looking at the chapters of this book, it is very interesting to see how Hennepin integrated his first book in his later works. A significant part of the chapters can already be found in Hennepin's book Beschryving van Louisania, in which he dedicates the second part to "de Zeden der Wilden", the manner of the natives (Hennepin, 1688, pp.121-158).

\section{Writing on the savages}

Hennepin starts his book, A New Voyage, with several accounts of events happening during La Salle's journey. This includes and ends with "Reflections of the Author of this Work, upon the Life and Death of the Sieur la Salle, whose Murderers kill'd one another", which he describes in Chapter VII (Hennepin, 1698, p. xx). For the next twenty-eight chapters, he gives a detailed description of "The Savages". In these descriptions, readers can discover their way of making war, the games they played, their cruelty, their manners, their characteristics, the behavior between one another and in general, and much more. Furthermore, he certainly does not forget to describe their lack of belief in God and the results of his ambition to convert them. He ends the book with an elaboration on how to establish good colonies, followed by a reflection on the Franciscans that were in New 
France before the Jesuits and his sentiments about the little progress in conversion that he and his fellow missionaries experienced.

\section{Nineteenth century critique}

In the books following Beschryving van Louisania, Hennepin added significant parts to his initial story that led to great criticism and even to a reputation as a liar. The reason for the doubt in his story has been explained by different scholars and will be briefly summarized in the subsequent section.

In his book Historical Scetches of Louisiana, Stoddard has presented an extensive outline of his criticism of Hennepin. Firstly, he argues that even if the missionary had reached the mouth of the Mississippi River before Sieur de la Salle, there still had been other voyageurs that had explored the area before him. Secondly, Stoddard explains, the distances Hennepin described having passed by boat are significantly longer in reality. Equivalently, the duration of seventeen days that it took Hennepin and his men to travel 1350 miles is not probable (Stoddard,1812, p.17). In the same way as the descent, he pretends to have traveled the river in a period of time that is physically impossible to have done. Another point of criticism was that the missionary failed to describe neither the mouth of the Mississippi nor the countries situated around, even though this should have been of great importance for an explorer. Lastly, the reasons he gave for not having mentioned his discovery of the Mississippi are not very credible as it was merely the fact that his descent to the mouth of the Mississippi resulted out of his misconduct and he did not want to take the triumph from La Salle (Stoddard, 1812, p.18). Furthermore, the fact that Hennepin published his new version after La Salle's death and after an incident between the two that forced Hennepin to demand safety in England does not make his story more believable (Stoddard, 1812, p.18).

\section{How does Hennepin describe 'the Other'?}

Before commencing with the analysis of Hennepin's writings about the Native Americans, it is important to keep Stephen Greenblatt's writings in mind. Greenblatt argues in his book Marvelous Possessions, that the "European representation of the New World tell us something about the European practice of representation" and this is the only fact we can be certain about (Greenblatt, 1991, p.7). He further elaborates his argument that the 
representation is not only shaped by the national origins of the writers, but also by other backgrounds. He presents that the descriptions can show relevant differences depending on whether they were written by catholic or protestant missionaries (Greenblatt, 1991, p.8). Similarly, another scholar put forward that it is important to keep in mind that "reallife contact experiences of missionaries, traders, soldiers, habitants and metropolitan administrators were filtered through the cultural perception of the European" (Jaenen, 1982, p.46).

The first chapter this section takes a closer look at Chapter XIII, "The Barbarians of the Northern America don't acknowledge a god. Of the pretended Souls of Terrestreal America". As the title already indicates, this chapter deals with the beliefs of the Native Americans. Hennepin observes that the natives do not believe in Deity, but at a later point adds that he could detect some form of belief in a higher spirit, although not necessarily in the God that Christian faith propagates (Hennepin, 1699, p.60). While he further explains the belief of the natives, he describes how they are "incapable of the common and ordinary Arguments and Reasonings that the rest of Mankind are led by upon this Subject; so dark and stupid are their Undertakings" (Hennepin, 1699, p.60). Hennepin continues about how they do not show any respect for their religion and see dreams as prophecy or commandments. Where he is only deriding their beliefs, he is more radical with the assessment of their medicine men, which he calls "Jugglers". Even though he first mentions that it is not likely that they are communicating with the devil, he adds that "one may venture to say, that the evil Spirit has a hand in the Tricks of these Jugglers, and makes use of them to amuse these poor People, and render them more incapable of receiving the Knowledge of the true God" (Hennepin, 1699, p.61). He further mentions a means of the devil to delude them, which is the belief in the souls of different animals (Hennepin, 1699, p.62). At the end of the chapter he again mentions their stupidity and foolishness (Hennepin, 1699, p.62). During that time it was very common among travel writers to see the devil in unknown or for them frightening traditions. The rituals of the Tupinamba for example seemed to have made a lasting impression on different travelers as well. Their traditional songs and performances had disturbed a particular traveler, Jean de Léry, so much, that after having accounted their traditions during a breakfast with them, he described them as being possessed by the devil (Greenblatt, 1991, p.14).

In Chapter XVII, which is called "Of the Marriages of the Savages in North America" Hennepin elaborates on the natives attitudes towards marriage and the relationships between men and women. Unlike the regulations of the Christian faith, the natives do not intend to share their lives until death tear them apart but to separate as soon as they do not love each other anymore (Hennepin, 1699, p.71). He further explains the manner of 
engaging amongst the natives before briefly evaluating their way of making love, both acted out in a different way than it is practiced in Europe. (Hennepin, 1699, p.72). After discussing jealousy between men and women, he revisits the topic of infidelity and tells the story of a Canadian woman who a group of native women tried to convince of taking another man while her husband was gone. Hennepin seems very appalled of that incident and says that "this great inconstancy, and continual change of Women, are two things very opposite to the Maxims of the Gospel, which we endeavor to instill into the Savages: 'Tis one of the most considerable Obstacles of the Faith" (Hennepin, 1699, p.74). It is thus the absence of all these European qualities or institutions that describes "The Savages". Accordingly, a description of them can be traced back to the description of the people of the Tupinamba (Brazil) by Andre Thevet in the $16^{\text {th }}$ century. He describes a brutal tribe that neither obliges to any law, nor faith or religion, nor has any sense of civility. (Jaenen, 1982, p.46). Hennepin's description of the natives in these two chapters was clearly biased by his occupation as a priest. As Greenblatt and Jaenen have stated, it is important to take into account the background of the author, and that this will determine his way of writing (Jaenen, 1982, p.46; Greenblatt, 1991, p.8).

In the past, the distinction between self and other occurred through religion and the affiliation to Christianity. The introduction of new behavioral rules worked as a means for the secular upper class to distinguish themselves from others, and at the same time define their self-image (Elias, 1993, p.54). In the next two chapters, Hennepin discusses some of the behavioral rules in order to present the natives. Before going into detail about the remaining chapters, it is essential to first introduce Norbert Elias' book, The civilizing process. The book was published in 1939 and was first available to a German speaking audience. Even though the book might suggest differently, it is not meant to be seen as a demonstration of European superiority compared to the uncivilized nations. It was written in order to show the process of the creation of a self-image that led to the emergence of a feeling of cultural superiority. Elias explains how the Europeans moved from their savage and barbaric past and came to be civilized (Linklater;Mennell, 2010, p.385). A possible starting point in this process was the emergence of civility as a concept, which happened at the time when knighthood dissociated itself from the Catholic Church. It can be interpreted as "an expression and a symbol of a social formation embracing the most diverse nationalities, in which, as in the Church, a common language was spoken, first Italian and then increasingly French" (Elias, 1993, p.47). The concept itself was greatly characterized by the writings of Erasmus of Rotterdam. His work "De civilitate morum puerilium" was a very popular handbook on how to behave and was published in 1530. Due to the great success it was translated into different languages and used as a schoolbook for boys (Elias, 1993, p.47). 
What influence these writings of Erasmus and the concept of civilization had on Hennepin can be observed in the following two chapters. As the title of Chapter XX already outlines, it is "a description of the Savages that go clothed, and those that do not". First, he elaborates on the attitude of the Northern Savages who used the skin of the animals they hunted in order to produce clothing. Over the next few pages, he describes in detail their clothing and accessories (Hennepin, 1699, pp.81-83). Moreover, he mentioned that when they visited the Indians in their cabins he demanded that the girls should cover themselves, which resulted in the positive effect of them developing shame and the feeling that they need to cover themselves (Hennepin, 1699, p.83). After that, he describes the Savages as "betwixt the frozen Sea and New Mexico" who seemed to be naked all the time (Hennepin, 1699, p.84). He wrote that "These Savages have really no manner of Shame to see themselves naked; nay they seem to glory in it" (Hennepin, 1699, p.84).

With his work, Erasmus did not only introduce a certain code of conduct, but he also introduced shame as an essential part of society (Elias, 1993, p.114). Norbert Elias has shown the interconnectedness of sociological change and psychology that took place through the civilization process. The internalization of the new code of conduct was greatly facilitated by the role that shame played in the society (Linklater;Mennell, 2010, p.395). It is interesting to see that Hennepin was very pleased with introducing the feeling of shame into the society of the Native Americans. This shows the influence his European descent had on his interpretation of the Indians.

He further elaborates that he is "nevertheless persuaded by the Scripture, that all Mankind are descended from Adam; and therefore the Savages as well as others, are sinners, and corrupted by their Birth, and that they will perish in their Sins if they don't receive the Gospel; for there is no other name by which Man can be saved, but the Name of Christ" (Hennepin, 1699, p.84). Furthermore, he explains, that these barbarians "violate the Law of Nature, and live in Stupidity" and that they will face God's punishment. He ends this chapter with a continuation of why they need to be saved by the Gospel (Hennepin, 1699, pp.84-85). The continuous mentioning of the stupidity of "The Savages" suggests the author's feeling of superiority over the Native Americans. According to Greenblatt, this is a characteristic of almost all missions. Whereas Hennepin is taking his superiority from the fact that he sees those believing in the Christian faith as the enlightened ones, other authors show other reasons for this. In most missions, the feeling of superiority not only stems from the advantages in weaponry, but interestingly, literacy played an important role as well. Others even saw the ability to speak Greek a distinguishing factor when comparing the barbarous to the civilized. The incapability to understand God who spoke to the people through writings shows the exclusion from being human, which positions the natives closer to being Apes. (Greenblatt, 1991, p.10). 
Chapter XXXI deals with the "barbarous and uncivil Manners of the Savages" (Hennepin, 1699, p.119). Hennepin opens the chapter with a statement saying that "the Savages have small regard to the Civilities of Europe" (Hennepin, 1699, p.119). He further elaborates on their bad manners, presenting many examples such as the continuously mentioned nakedness without any shame or their habit of doing "the Necessities of Nature before all the World, without the least scruple, and without regard to any Man" (Hennepin, 1699, p.120). Furthermore, he underlines the conduct between men and women, which is, although done mostly in private, done with such little cautiousness that the couples are often surprised by their fellow tribesmen or women. Moreover, he states, "the Savages observe none of the Rules of that natural Honesty which is used among the Europeans of both Sexes" (Hennepin, 1699, p.120). By this, he is referring to the brutish behavior in most of their undertakings. On the following pages he is mostly referring to the lack of hygiene, the act of cleaning their hands by rubbing them on their hair and faces after having eaten greasy meat, eating the lice of their children's head and lying on the floor like dogs while eating. In sum he characterizes them in a very brutal and animal like way (Hennepin, 1699, pp.120-121).

This way of presenting the natives is very close to other $16^{\text {th }}$ century writers. The French travelers identified the Native Americans as a people lacking civility, which they took as an explanation for their cruelty (Jaenen, 1982, p.46). Other authors, such as Buffon, interpret their naturalness as still being very close to animality and do not necessarily distinguish them from that (Jaenen, 1982, p.47). It is apparent that both of these interpretations can be observed in Hennepin's writing about the American tribes. As Bausum suggested, for writers propagating their religious and colonizing view, the image of the cruel savage is typical (Jaenen, 1982, p.44). Furthermore, the presentation of the cruelty of the savages was clearly used as a justification for the need of colonizing and converting the Native Americans (Jaenen, 1982, p.45).

In Hennepin's last chapter used for the analysis, he outlines "the great Indifference of the Humours of the Savages" (Hennepin, 1699, p.123). This indifference is not only recognizable in material things but also in the Christian Faith that Hennepin is trying to convert them to. What is distinct to the chapter is his conclusion, which can be interpreted as the result, but also as the summary of his writings about the natives and a suggestion for the French King:

"It's necessary to civilize this Nation before they be made to embrace the Christian Faith. If they be not under the Yoak, it's in vain to labour their Conversion, unless God by a particular Grace should do some Miracle in favor of this People" (Hennepin, 1699, p.125). 


\section{Discussion and conclusion}

As compared to other travel accounts on North America, Hennepin's writings do not only differ in the representation of the natives, but with respect to the reception of his books in Europe. Whereas his first book was undisputedly a great success, the books following earned him the reputation of being a liar due to the fact that he tried to steal La Salle's success of exploring the mouth of the Mississippi.

Hennepin's writings are also in contrast with those of other authors in terms of content. The disparity however lies not in the fact that others have explored other parts in the New World, but can be traced back to the background of the authors themselves. Whereas some travelers came for the mere task of exploring, others came in order to establish trade relations, and again others with the aspiration to conquest the land. In Hennepin's case, the conversion of the natives was the main motive, even though his passion about traveling would have probably been reason enough for him to go there. Nevertheless, Hennepin enjoyed a great amount of religious education that influenced his writings, but with his European descent he was destined to see the natives through a filter and interpret accordingly.

The analysis has proven the importance of the authors background which has been mentioned by several authors previously. The chosen chapters have clearly shown that not only Hennepin's civilized European descent, but also his occupation have greatly influenced his writings about the American tribes. His judgment of the natives as being fundamentally unintelligent can be traced back to his frustration due to the difficulties of converting them. This is especially apparent when considering that he exclusively devaluated them in that way in connection to their disregard for the Christian faith. Furthermore, his presentation of them as animal-like and brutish could already be observed in other traveler's works, connected to the lack of civility that was attributed to them. As presented in the analysis, this interpretation of lack of civility however stems from a new code of conduct introduced in the16th century in Europe. These factors however influenced Hennepin's writings about the American tribes significantly, and led to a very negative representation as distinguished from other authors with completely different views.

As Stephen Greenblatt said, "We can be certain only that European representations of the New World tell us something about the European practice of representation" (Greenblatt, 1991, p.7). 


\section{Bibliography}

Anonymous (2013). Canadian Museum of Civilization Corporation. Retrieved $7^{\text {th }}$ of May 2013 from http://www.civilization.ca/virtual-museum-of-new-france/the-explorers/louis-hennepin-1678-1680/

Anonymous (2013 a). The Dictionary of Canadian Biography Online. Retrieved $7^{\text {th }}$ of May 2013 from http://biographi.ca/oogo04-119.01-e.php?id_nbr=841.

Elias, N. (1993). The Civilizing Process. Sociogenetic and Psychogenetic Investigations. Oxford: Blackwell.

French, B.F. (1846). Historical Collections of Louisiana. New York: Wiley and Putnam.

Greenblatt, S. (1991). Marvelous Possessions. The Wonder of the New World. Chicago:The University of Chicago Press.

Hennepin, L. (1688), Beschryving van Louisiana, nieuwelijks ontdekt ten zuid-westen van NieuwVrankryk. Amsterdam: Jan ten Hoorn.

Hennepin, L. (1699). A Continuation of the New Discovery. London: H. Bonwick.

Jaenen, C.J. (1982). 'Les Sauvages Ameriquains': Persistence into the 18th Century of Traditional French Concepts and Constructs for Comprehending Amerindians, Ethnohistory 29(1), 43-56.

Lemay, H. (1933). Bibliographie des bibliographies du P. Louis Hennepin, récollet. Montreal: s.n..

Lemay, H. (1937). Bibliographie du Père Louis Hennepin, recollect: les pièces documentaires. Montreal: s.n.

Linklater, A \& Mennell, S. (2010). Norbert Elias, 'The Civilizing Process: Sociogenetic and Psychogenetic Investigations' - And Overview and Assessment. History and Theory 49(3), 384-411.

Louant, A. (1950). Le P. Louis Hennepin, nouveaux jalons pour sa biographie. Revue d'Histoire Ecclesiastique 45(1-2), 187-211. 
Shea, J.G. (1855). History of the Catholic Missions among the Indian Tribes of the United States, 1529-1854. New York: Edward Dunigan \& Brother.

Stoddard, A. (1812). Scetches, Historical and Descriptive, of Louisiana. Philadelphia: Mathew Carey. 


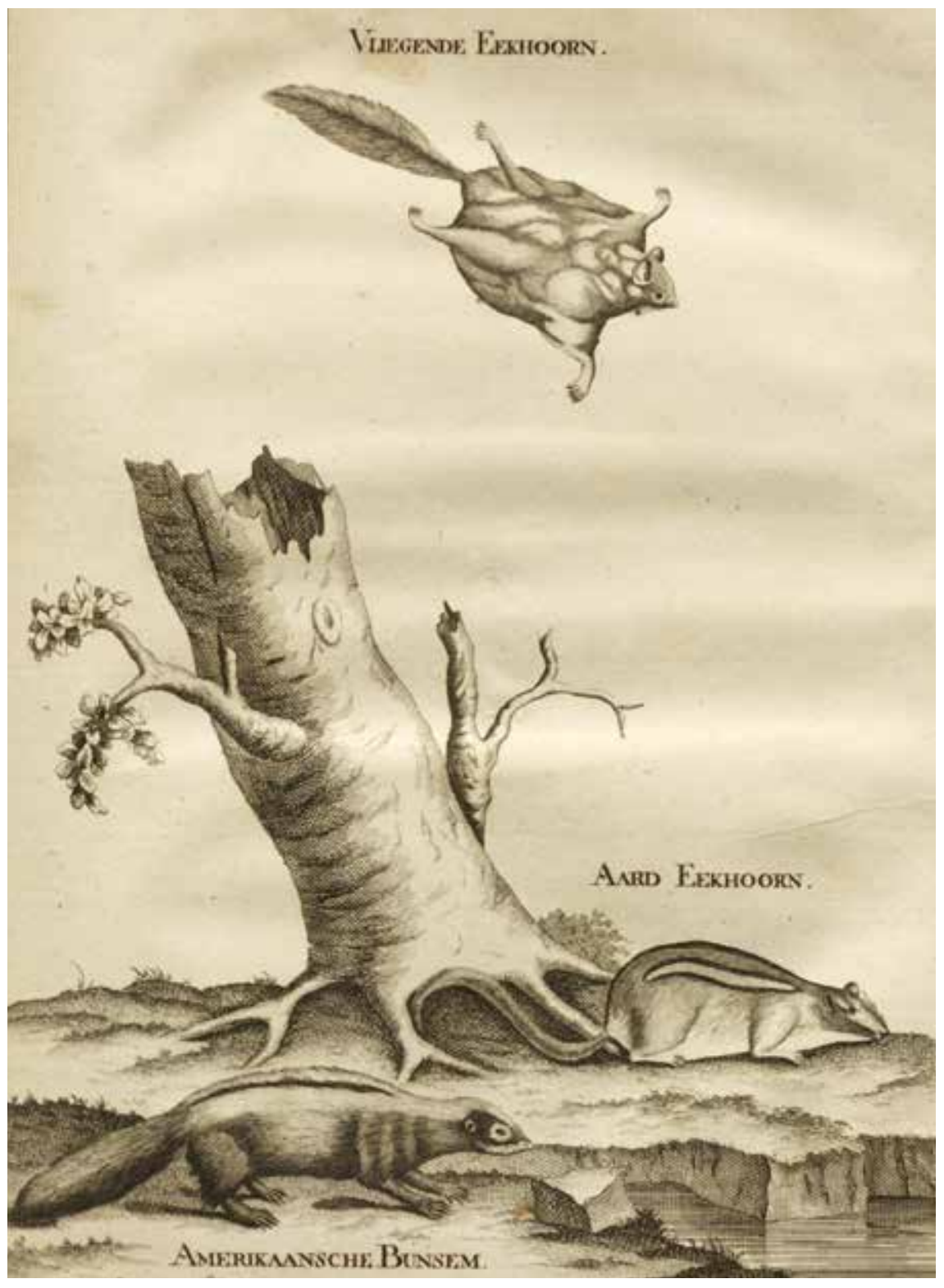

Animals of the New World

Source: Kalm, P. (1772). Reis door Noord Amerika. Utrecht: J. van Schoonhoven en Comp., pp. 140-141. 